\title{
Genovefa Jēča, medicīnas doktore, profesore
}

(1921-2011)

Genovefa Jēča dzimusi 1921. gada 18. aprīlī. Viṇa nodzīvoja skaistu un garu mūžu un aizsaulē aizgāja 2011. gada 6. aprīlī - tikai trīspadsmit dienu pirms savas deviņdesmitās dzimšanas dienas.

Genovefa dzimusi Rēzeknes apriņ̧̧̧a Maltas pagastā dārznieka Jāņa Jēča ǵimenē. Pirmās skolas gaitas Genovefa sāka Maltas pagasta Ziedukalna pamatskolā, tad sekoja mācības Rēzeknes vidusskolā, bet pēc tām - studijas Latvijas Universitātes Medicīnas fakultātē, ko viņa pabeidza 1946. gadā. Viņas vien̄̄gā darbavieta no 1947. gada līdz pat aiziešanai pensijā bija saistīta ar Anatomikumu. Pirmos gadus (1947-1950) viņa strādāja Latvijas Valsts universitātes (LVU) Histoloǵijas katedrā, bet no 1950. gada - par docētāju Rīgas Medicīnas institūta / Latvijas Medicīnas akadēmijas Cilvēka normālās anatomijas katedrā. Veiksmīga abu morfoloǵisko disciplīnu apguve kḷuva par pamatu viñas izcilajiem panākumiem mācību un zinātniskajā darbā. No 1973. līdz 1992. gadam viņa bija Anatomijas katedras vadītāja, pēc tam profesore konsultante. 1961. gadā Genovefa Jēča kḷuva par docenti, bet 1978. gadā - par profesori.

Genovefa Jēča bija precējusies ar LVU Medicīnas fakultātes Dzemdniecības un ginekologijas katedras aspirantu, vēlāk docētāju Sergeju Volkovu. Viṇu gimenē piedzima dēls Andrejs un meita Valda. Abi Genovefas Jēčas un Sergeja Volkova bērni kḷuva par ārstiem, apprecējās ar ārstiem un arī daži viņu bērni ir ārsti. Tā Genovefas Jēčas ǵimene nu jau trijās paaudzēs ir izveidojusies par ārstu dinastiju.

Savā garajā darba mūžā Genovefa Jēča strādāja arī ar anatomijas studentu zinātnisko pulciņu. Daudzi jo daudzi vēlāk izcili ārsti klīnicisti pirmos soḷus zinātnē spēruši profesores Genovefas Jēčas vadībā - docents Edvīns Platkājis, profesors Jānis Gaujēns, profesors Jānis Zaļkalns, Marija Zvaigznīte, Nikolajs Mazurenko un daudzi citi. Kopš 1975. gada viṇa 
Anatomijas katedrā katru gadu rīkoja studentu darbu konkursu "Labākais anatomiskais preparāts".

Profesore Jēča ir vadījusi četras doktora disertācijas un bijusi morfoloǵisko daļu vadītāja septiņām klīnisko disciplīnu disertācijām. Viṇa sistemātiski attīstīja un uzlaboja Anatomijas katedras mācību metodisko darbu. Par to liecina profesores vienpadsmit izstrādātie metodiskie norādījumi latviešu, latīņu, krievu un angl̦u valodā, kā arī divas metodiskās vēstules “Apakšējo ekstremitāšu vēnu slimības un to ārstēšana” (1978) un “Apakšējo ekstremitāšu vēnu ķirurǵiskās ārstēšanas metožu klīniski morfoloǵiskais pamatojums" (1985).

Medicīnas zinātņu kandidāta disertāciju Genovefa Jēča aizstāvēja 1957. gadā. Šajā darbā viņa atklāja, ka apakšstilba virspusējo un dziḷo vēnu caurviju anastomožu vārstules uztur kāju vēnās normālu hemodinamiku. Genovefas Jēčas doktora disertācija ir ontoǵenētiskā aspektā izvērsts kandidāta disertācijas tēmas turpinājums. Eksperimentā ar kaķiem viṇa atklāja, ka kāju vēnu caurviju anastomozēm ir divēja inervācija - no ādas nervu zariem un no dziḷo kājas nervu zariem. Viņa arī konstatēja, ka kāju vēnu embrioǵenēzē apvalku diferenciācija embrionālo vēnu sienā sākas tikai pēc tam, kad to sasniegušas nervu šksiedras.

Genovefa Jēča regulāri lasīja zinātniski populāras lekcijas par cilvēka ķermeņa uzbūvi un veselības saglabāšanu gan Anatomijas muzejā, gan Zinību biedrībā, radio un televīzijā. 1997. gadā viņas darbs tika novērtēts ar nozīmi "Veselības aizsardzības teicamnieks". Šajā pašā gadā viñai tika arī piešksirts Latvijas Ārstu biedrības goda biedres nosaukums.

Genovefa Jēča bija ilggadēja Latvijas Anatomu, histologu un embriologu zinātniskās biedrības sekretāre un tās darba organizatore. 2001. gadā profesorei Jēčai par izcilu pedagoǵisko un zinātnisko darbu tika piešksirta Jēkaba Prīmaņa balva.

Genovefas Jēčas zinātniskie sasniegumi bija pazīstami ar̄̄ ārpus Latvijas robežām. No 1974. līdz 1990. gadam viņa bija PSRS Medicīnas Zinātṇu akadēmijas Problēmu komisijas locekle, recenzēja zinātnisko tēmu projektu pieteikumus, kā arī asinsvadu un nervu anatomiskos pētījumus, kas bija veikti dažādos medicīnas institūtos - Astrahaṇā, Harkovā, Jaroslavḷā, Kišiñevā, Orenburgā, Vitebskā, Zaporožjē, Maskavā, Pēterburgā un citur.

Aina Dālmane,

Dr. habil. med. 